\title{
Pendekatan Konstruktivisme dalam Pembelajaran Tematik Terpadu di SD Negeri Sumogawe 01 Kab. Semarang
}

\author{
Nuryati $^{1}$ \& Endang Fauziati ${ }^{2}$
}

Prodi Magister Pendidikan Dasar, Universitas Muhammadiyah Surakarta, Indonesia

$\bowtie$ E-mail: aka80794@gmail.com

\begin{abstract}
Abstrak
Penelitian ini bertujuan untuk menganalisis Pendekatan Kontruksivisme dalam Pelaksanaan Pembelajaran Tematik Terpadu di SD Negeri Sumogawe 01, Kab.Semarang. Metode yang digunakan dalam penelitian ini adalah deskriptif kualitatif. Penelitian ini dilakukan pada guru dan peserta didik. Teknik pengambilan data yang digunakan adalah observasi, wawancara dan dokumentasi. Instrument Analisis data dilakukan dengan (1) Reduksi data; peneliti melakukan proses pemilihan atau seleksi, pemusatan perhatian atau pemfokusan, penyederhanaan, dan pengabstraksian dari semua jenis informasi yang mendukung data penelitian. (2) Sajian data; sekumpulan informasi yang memberi kemungkinan kepada peneliti untuk menarik simpulan dan pengambilan tindakan.(3) Penarikan Simpulan/Verifikasi; Peneliti harus berusaha menemukan makna berdasarkan data yang telah digali secara teliti, lengkap, dan mendalam. Teknik penilaian untuk memeriksa keabsahan data menggunakan triangulasi. Triangulasi yang digunakan triangulasi sumber dan triangulasi metode. Hasil penelitian ini menunjukkan bahwa (1) Pendekatan kontruksivisme untuk memadukan muatan pelajaran menjadi satu tema. (2) Guru dapat menanamkan pemahaman peserta didik tentang pembelajaran tematik. (3) Pembelajaran tidak hanya berpusat pada guru, tetapi mengaktifkan peserta didik untuk belajar. Kesimpulan Aliran konstruktivisme berpandangan bahwa belajar merupakan hasil konstruksi peserta didik terhadap pengalaman belajarnya.
\end{abstract}

Kata Kunci: Konstruktivisme; Pembelajaran; Tematik Terpadu.

\begin{abstract}
The purpose of this study aims to analyze the Constructivism Approach in the Implementation of Integrated Thematic Learning at SD Negeri Sumogawe 01, Kab. Semarang. Method research is descriptive qualitative. This research was conducted on teachers and students. Data collection techniques used are (1) observation, interviews and documentation. Instrument Data analysis was carried out by (1) data reduction; researchers carry out the process of selecting, focusing, simplifying, and abstracting all types of information that support research data. (2) data presentation; a collection of information that gives researchers the possibility to draw conclusions and take action. (3) Conclusion Drawing or verification; Researchers must try to find meaning based on data that has been dug carefully, completely, and deeply. Assessment technique to check the validity of the data using triangulation. The triangulation used is source triangulation and method triangulation. The results of this study indicate that (1) the constructivism approach is to integrate lesson content into one theme. (2) Teachers can instill students understanding of thematic learning. (3) Learning is not only centered on the teacher, but activates students to learn. Conclusion Constructivism is of the view that learning is the result of students' construction of their learning experience.
\end{abstract}

Keywords: Constructivism; Learning; Integrated Thematic. 


\section{PENDAHULUAN}

Pemerintah

telah menetapkan kurikulum sebagai salah satu alat untuk mencapai tujuan pendidikan yaitu kurikulum 2013. Kurikulum 2013 dirancang dalam bentuk tematik yang terdiri dari tema-tema dan dibagi ke dalam setiap subtema. Untuk membantu peserta didik dalam pembelajaran tematik pemerintah menyiapkan sebuah sumber belajar berupa buku tema dan buku panduan bagi guru. Pembelajaran diharapkan dapat mengkondisikan antara perkembangan ilmu pengetahuan dan teknologi yang dihubungkan dengan segala permasalahan yang terjadi dimasyarakat, untuk itu dapat diterapkan pembelajaran tematik.

Daryanto berpendapat bahwa pembelajaran tematik diartikan sebagai pembelajaran yang menggunakan tema untuk mengaitkan beberapa mata pelajaran sehingga dapat memberikan pengalaman yang bermakna kepada peserta didik. Jaringan tema yang dirancang dalam pelaksanaan pembelajaran tematik sebagai alat yang dapat digunakan untuk mengetahui keterkaitan isi antara satu mata pelajaran dengan mata pelajaran lainnya. Dengan demikian, penggunaan jaringan tema merupakan jalan pembuka. yang menghasilkan upaya terjadinya pembelajaran bermakna (Fitriadi \& Sabri, 2019).

Pengertian pembelajaran tematik menurut Rusman (2015: 139) “pembelajaran tematik merupakan pembelajaran terpadu sebagai suatu sistem pembelajaran yang memungkinkan peserta didik baik secara individual maupun kelompok aktif untuk menggali dan menemukan konsep serta prinsip-prinsip keilmuan secara holistik, bermakna, autentik, dan aktif (Fitriadi \& Sabri, 2019).

Beberapa pendapat sebelumnya dipahami bahwa pembelajaran tematik terpadu adalah pembelajaran yang terintegrasi dlam satu tema yang menggunakan satu tema untuk mengaitkan beberapa mata pelajaran sehingga dapat membeikan pengalaman bermakna bagi peserta didik dengan prinsip-prinsip keilmuan secara holistik, bermakna, autentik, dan aktif. Pembelajaran tematik juga akan mampu menghubungkan peserta didik dengan kehidupan nyata. Pembelajaran tematik dapat menumbuhkan motivasi bagi peserta didik untuk terlibat di dalam pembelajaran secara aktif dan dapat menyelesaikan masalah dalam pemeblajaran.

$$
\text { Pembelajaran tematik lebih }
$$
menekankan konsep belajar melakukan sesuatu. Untuk itu guru dituntun dapat merancang pengalaman belajar yang kebermakna bagi peserta didik. Pengalaman belajar yang berkaitan dengan unsur-unsur konseptual akan menjadikan proses pembelajaran lebih efektif. Keterkaitan konsep antar mata pelajaran yang dipelajari akan membentuk skema, sehingga peserta didik akan memperoleh keutuhan dan kebulatan pengetahuan. Jadi pembelajaran tematik merupakan pembelajaran yang didasarkan dari sebuah tema yang digunakan untuk mengaitkan beberapa konsep mata pelajaran, sehingga anak akan lebih mudah memahami sebuah konsep pembelajaran yang diajarkan.

Salah satu landasan filosofis yang mempengaruhi pembelajaran tematik Kontruktivisme menganggap pengalaman langsung peserta didik sebagai kunci dalam pembelajaran. Sedangkan pengetahuan sebagai hasil dari konstruksi atau bentukan manusia. Manusia mengkonstruksi pengetahuan yang diperoleh melalui interaksi dengan obyek, fenomena, pengalaman dan lingkungannya. Pengetahuan diperoleh dari hasil interpretasi dari masing - masing 
peserta didik dan tidak dapat ditransfer begitu saja dari seorang guru. Interpretasi yang diwujudkan dalam keaktifan peserta didik dari rasa ingin tahunya sangat berperan dalam perkembangan pengetahuannya (Anu Beatrix, Ruminitai, 2017).

Prinsip dasar yang melandasi filsafat konstruktivisme adalah semua pengetahuan dikonstruksikan dan bukan dipersepsi secara langsung oleh indera (penciuman, perabaan, pendengaran, perabaan, dan seterusnya) sebagaimana asumsi kaum realis pada umumnya. Tidak ada teori konstruktivisme yang tunggal, tetapi sebagian besar para konstruktivis setidaknya memiliki dua ide utama yang sama; (1) pembelajar aktif dalam mengkonstruksikan pengetahuannya sendiri. (2) interaksi sosial adalah aspek penting untuk mengkonstruksian pengetahuan (Supardan, 2016).

Kontruksivisme sebagai pendekatan yang memiliki posisi filosofis dalam pendekatan dan strategi pembelajaran.Karena itu konstruktivisme sangat berpengaruh dalam bidang pendidikan, yang memunculkan beragamnya metode/strategi pembelajaran baru. Sehingga kontruksivisme diharapkan mampu menyelesaikan pelaksaan pembelajaran tematik integrative di SD Negeri Sumogawe 01 Kab.Semarang. Ditemukannya hal yang terkait dengan permasalahan pembelajaran tematik integratif. Diantaranya: (1) Ketika pembelajaran berlangsung guru masih memisahkan pembelajaran berdasarkan muatan pelajaran. (2) Guru kesulitan dalam menanamkan pemahaman pembelajaran tematik terpadu kepada peserta didik. (3) Proses pembelajaran masih berpusat pada guru. Dari temuan - temuan hasil observasi, kemudian dilakukan pendekatan kontruksivisme untuk pelaksanaan pembelajaran tematik integrative.
Tujuan dari penelitian ini untuk menganalisis pendekatan kontruktivisme untuk mengaktifkan peserta didik dalam pelaksanaan pembelajaran tematik terpadu di SD Negeri Sumogawe 01 Kab. Semarang.

\section{METODE PENELITIAN}

Pendekatan Penelitian yang digunakan dalam penelitian ini adalah dengan metode penelitian deskriptif kualitatif. Adapun tujuan penelitian deskriptif kualitatif yaitu untuk mengangkat dan membuat gambaran secara sistematis mengenai fakta-fakta, keadaan, variable dan fenomena-fenomena yang terjadi tentang pelaksanaan pembelajaran tematik integrative dengan pendekatan kontruktivisme di Sekolah Dasar. Metode kualitatif adalah metode penelitian yang digunakan untuk meneliti kondisi objek yang alamiah, di mana peneliti adalah instrument kunci, dan hasil penelitian kualitatif ini lebih menekankan pada makna daripada generalisasi (Darmalaksana, 2020).

Tempat penelitian di salah satu Sekolah Dasar Negeri di Kabupaten Semarang dan waktu penelitiannya dimulai dari tanggal 18 Juli 2020 sampai dengan tanggal 10 Maret 2021. Subjek penelitian adalah guru kelas 4 dan peserta didik. Sedangkan Sumber datanya adalah Penerapan pelaksanaan pembelajaran tematik integratif. Tehnik pengumpulan datanya dengan tehnik observasi, wawancara dan dokumentasi. Adapun instrument penelitian sebagai berikut: (1) Observasi dilakukan dikelas 4 pada kegiatan pembelajaran tatp muka (luring). Wawancara dilakukan terhadap guru kelas 4. (3) Dokumen yang di peroleh dari yang bersangkutan dengan pembelajaran yang diminta secara langsung kepada guru kelas yang diteliti.

Data yang diperoleh kemudian 
dianalisis. Analisis data dilaksanakan melalui tiga tahap yaitu, (1) Reduksi data, (2) Sajian data, (3) Menyimpulkan data. Reduksi data adalah suatu bentuk analisis untuk mempertajam, memilih, memfokuskan, mengurangi, dan menyusun data dalam suatu cara dimana kesimpulan akhir dapat digambarkan. Dalam penelitian kualitatif, penyajian data bisa dilakukan dalam bentuk uraian singkat, hubungan antar kategori, dan lainnya. Miles dan Huberman (Darmalaksana, 2020) menyatakan bahwa yang sering digunakan untuk menyajikan data dalam penelitian kualitatif adalah dengan teks naratif. Sedangkan menyimpulkan data dengan mengambil intisari dari sajian data yang telah terorganisir dalam bentuk pernyataan kalimat yang singkat tetapi mengandung pengertian luas.

Uji keabsahan data pada penelitian ini menggunakan triangulasi. Peneliti dalam triangulasi melakukan data sekaligus menguji kredibilitas data. Cara mengecek kredibilitas data dengan tehnik pengumpulan data dari berbagai sumber. Peneliti menggunakan triangulasi sumber dan metode.

\section{HASIL DAN PEMBAHASAN Pendekatan Kontruktivisme}

Pendekatan kontruksivisme dalam pembelajaran menggambarkan bahwa, (1) pengetahuan dibangun oleh peserta didik sendiri, baik secara personal maupun sosial, (2) pengetahuan tidak dapat dipindahkan dari guru ke peserta didik, kecuali melalui keaktifan peserta didik untuk menalar, (3) peserta didik aktif mengkonstruksi secara terus menerus, sehingga selalu terjadi perubahan konsep menuju ke yang lebih rinci, lengkap, serta sesuai dengan konsep ilmiah, dan 4) guru sekedar membantu menyediakan sarana dan situasi agar proses konstruksi peserta didik dapat terlaksana (guru sebagai fasilitator) (Liadi et al., 2018).

Pendekatan konstruktivisme, belajar merupakan proses aktif peserta didik mengkonstruksi arti, wacana, dialog, pengalaman fisik, dll. Proses tersebut bercirikan, a) belajar berarti membentuk makna. Makna diciptakan oleh peserta didik dari apa yang dilihat, dengar, rasakan, dan alami, b) konstruksi arti merupakan proses yang terus menerus. Setiap kali berhadapan dengan fenomena atau persoalan yang baru, peserta didik akan selalu mengadakan rekonstruksi, c) belajar bukanlah kegiatan mengumpulkan fakta, melainkan suatu proses pengembangan pemikiran dengan membentuk suatu pengertian yang baru. Belajar bukanlah hasil dari perkembangan, melainkan perkembangan itu sendiri, yang menuntut penemuan dan pengaturan kembali pemikiran seseorang peserta didik, d) proses belajar yang sebenarnya terjadi ada pada waktu skema seseorang dalam kesenjangan yang merangsang pemikiran lebih lanjut. Situasi ketidakseimbangan (disequilibrium) adalah situasi yang baik untuk memacu belajar, e) hasil belajar dipengaruhi oleh pengalaman peserta didik dengan dunia fisik dan lingkungannya, dan f) hasil belajar seseorang tergantung pada apa yang telah diketahui peserta didik, yaitu konsep-konsep, tujuan, dan motivasi yang mempengaruhi interaksi dengan bahan yang dipelajari.

Kegiatan belajar adalah kegiatan aktif peserta didik menemukan sesuatu dan membangun sendiri pengetahuannya, bukan proses mekanik untuk mengumpulkan fakta. Peserta didik bertanggungjawab atas hasil belajarnya. Peserta didik membuat penalaran atas apa yang telah dipelajarinya dengan cara mencari makna, membandingkannya dengan apa yang telah diketahui dan menyelesaikan 
ketidaksamaan antara yang telah diketahui dengan apa yang diperlukan dalam pengalaman baru. Belajar yang bermakna terjadi melalui refleksi, pemecahan konflik, dialog, penelitian, pengujian hipotesis, pengambilan keputusan, dan dalam prosesnya disesuaikan dengan tingkat pemikiran yang selalu diperbaharui sehingga menjadi semakin lengkap.

Bagi konstruktivisme, pembelajaran bukanlah kegiatan memindahkan pengetahuan (transfer of knowledge) dari guru ke peserta didik, melainkan kegiatan yang memungkinkan peserta didik membangun sendiri pengetahuannya (belajar sendiri). Pembelajaran adalah partisipasi guru bersama peserta didik dalam membentuk pengetahuan, membuat makna, mencari kejelasan, bersikap kritis, dan mengadakan justifikasi.

Guru dalam teori pembelajaran kontruktivisme berperan sebagai mediator dan fasilitator, dapat menerima dan menghormati upaya-upaya peserta didik untuk membentuk suatu pengertian baru, sehingga dapat menciptakan berbagai kemungkinan untuk peserta didik berkreasi. Membebaskan peserta didik dari beban ikatan beban kurikulum dan membolehkan peserta didik(Rahmawati, Chumdari, 2021).

Pengaruh Konstruktivisme terhadap strategi pembelajaran penguasaan yang luas dan mendalam, seorang guru dituntut untuk menguasai beragam strategi pembelajaran sehingga dapat disesuaikan dengan kebutuhandan situasi peserta didik. Strategi yang disusun guru hanyalah suatu alternatif dalam pembelajaranda yang perlu diperhatikan dalam konstruktivisme ialah mengevaluasi hasil belajar peserta didik. Dalam mengevaluasi, guru sebenarnya menunjukkan kepada peserta didik bahwa pikiran/ pendapat mereka tidak sesuai untuk persoalan yang dihadapi berdasarkan prinsip atau teori tertentu. Kebenaran bukanlah hal yang dicari, namun berhasilnya suatu proses (viable) adalah hal yang dinilai.

Proses penilaian dalam pembelajaran konstruktivisme tidak tergantung pada bentuk penilaian yang menggunakan paper and pencil test atau bentuk tes objektif. Bentuk asesmen yang digunakan disebut authentic assessment diantaranya; portofolio, observasi proses, dinamika. Penilaian menurut Akhmat Susrajat bahwa penilaian (assessment) adalah penerapan berbagai cara dan penggunaan beragam alat penilaian untuk memperoleh informasi tentang sejauh mana hasil belajar peserta didik atau ketercapaian kompetensi (rangkaian kemampuan) peserta didik. Sedangkan menurut Rusli Lutan (2000:9) assessment termasuk pelaksanaan tes dan evaluasi. Jadi penilaian adalah alat untuk mengukur ketercapaiannya peserta didik dari hasil belajar. Hasil belajar berupa terjadinya perubahan tingkah laku pada diri seseorang yang dapat diamati dan diukur bentuk pengetahuan, sikap dan keterampilan.

Pengetahuan hasil rekonstruksi kita sendiri kemungkinan adanya transfer pengetahuan dari seseorang kepada orang lain. Pengetahuan dapat ditransfer dapat ditrensfer oleh guru dengan cara mentransfer suatu konsep, ide, dan pengertian kepada peserta didik, maka pemindahan itu harus diinterpretasikan, ditransformasikan dan dikonstruksikan oleh peserta didik itu sendiri lewat pengalamannya. Banyaknya peserta didik yang salah menangkap (misconception) apa yang diajarkan guru itu menunjukkan bahwa pengetahuan tidak dapat begitu saja dipindahkan, melainkan harus dikonstruksikan, atau di interpretasikan, dan ditransformasikan sendiri oleh peserta didik.

Gagasan Konstruktivisme mengenai 
pengetahuan adalah sebagai berikut; a) Pengetahuan bukanlah gambaran dunia kenyataan belaka, tetapi selalu merupakan konstruksi kenyataan melalui kegiatan peserta didik (Mind as inner individual representation), b). Peserta didik mengkonstruksi sendiri skema kognitif, kategori, konsep, dan struktur dalam membangun pengetahuan, sehingga setiap individu akan memiliki, skema kognitif, kategori, konsep, dan struktur yang berbeda. Dalam hal ini proses abstraksi dan refleksi seseorang akan sangat berpengaruh dalam konstruksi pengetahuan (Reflection/ Abstraction as primary), c) Pengetahuan dibentuk dalam struktur konsep masingmasing.individu peserta didik (Fitriadi \& Sabri, 2018).

Konstruktivisme dalam pembelajaran menggambarkan bahwa, (1) Pengetahuan dibangun oleh peserta didik sendiri, baik secara personal maupun social. (2) PPngetahuan tidak dapat dipindahkan dari guru ke peserta didik, kecuali melalui keaktifan peserta didik sendiri untuk menalar. (3) Peserta didik aktif mengkonstruksi secara terus menerus, sehingga selalu terjadi perubahan konsep menuju ke yang lebih rinci, lengkap, serta sesuai dengan konsep ilmiah, mendukung penyampaian materi pada saat pelaksanaan pembelajaran, guru juga mempersiapkan media pembelajaran yang akan digunakan dalam pembelajaran. (4) Guru sekedar membantu menyediakan sarana dan situasi agar proses konstruksi peserta didik dapat terlaksana (guru sebagai fasilitator).

\section{Pembelajaran Tematik Terpadu}

Pembelajaran tematik terpadu satu tema untuk mengaitkan beberapa mata pelajaran sehingga dapat memberikan pengalaman bermakna kepada peserta didik. Melalui pembelajaran tematik, diajak memahami konsep-konsep yang dipelajari melalui pengalaman langsung dan menghubungkannya dengan konsep lain yang sudah dipahaminya (Muhsinin et al., 2019).

Rusman (Rahmawati, Chumdari, 2021)menyatakan pembelajaran tematik merupakan model pembelajaran terpadu yang menggunakan pendekatan tematik yang melibatkan beberapa pelajaran untuk memberikan pengalaman bermakna kepada peserta didik. Pembelajaran bermakna dikarenakan dalam pembelajaran melalui tematik, peserta didik akan memahami konsep-konsep yang mereka pelajari melalui pengalaman langsung dan menghubungkannya dengan konsep lain yang dipahaminya Pembelajarn tematik terpadu ini bertolak dari suatu tema yang dipilih dan dikembangkan oleh guru bersama peserta didik dengan mempehatikan keterkaitan antar pelajaran. Pembelajaran tematik menawarkan model model pembelajaran menjadikan aktivitas pembelajaran itu relevan dan penuh makna bagi peserta didik.

Terdapat sembilan prinsip yang mendasari pembelajaran tematik menurut Mamat SB, dkk (Utari et al., 2016): (1) Terintegrasi dengan lingkungan atau bersifat kontekstual. (2) Memiliki tema sebagai alat pemersatu beberapa muatan pelajaran bahan kajian. (3) Menggunakan prinsip belajar sambil bermain dan menyenangkan. (4) Pembelajaran memberikan pengalaman langsung yang bermakna. (5) Menanamkan konsep dari berbagai muatan pelajaran atau bahan kajian dalam suatu proses pembelajaran tertentu. (6) Pemisahan atau pembedaan antara satu muatan dengan muatan pelajaran lain sulit dilakukan. (7) Pembelajaran berkembang sesuai dengan kemampuan, kebutuhan, dan minat peserta didik. (8) Pembelajaran bersifat fleksibel. (9) Penggunaan variasi metode dalam 
pembelajaran.

\section{Pendekatan Kontruksivisme Pembelajaran Tematik Terpadu}

Dalam

Aliran konstruktivisme melihat pengalaman langsung peserta didik sebagai kunci dalam embelajaran. Maksudnya isi atau materi pembelajaran perlu dihubungkan dengan pengalaman langsung peserta didik secara langsung. Aliran konstruktivistik berpendapat bahwa pengetahuan adalah hasil konstruksi atau bentukan peserta didik. Peserta didik mengkonstruksi pengetahuanya melalui interaksi dengan objek, fenomena, pengalaman, ilustrasi dan lingkungannya. Pengetahuan tidak dapat ditransfer begitu saja dari seorang guru kepada peserta didik tetapi harus diinterpretasikan sendiri oleh setiap peserta didik.

Nurhayati menjelaskan bahwa pendekatan konstruktivistik merupakan model pembelajaran yang menfokuskan pada aktivitas peserta didik. Tujuan pembelajaran dengan pendekatan konstrukivisme yaitu mengacu pada kesuksesan peserta didik dalam mengorganisasikan pengalaman belajar. Peran guru dalam pembelajaran ini tidak dominan karena pembelajaran ini menempatkan guru sebagai mediator, fasilitator dan motivator. Sejalan dengan pendekatan konstruktivistik yang berpandangan bahwa melalui pengalaman langsung peserta didik dapat mengkonstruksi pengetahuan yang diperolehnya, pembelajaran tematik juga menyajikan proses belajar yang nyata dengan kehidupan peserta didik (Rahmawati, Chumdari, 2021).

Pendekatan konstruktivistik dan pembelajaran tematik, keduanya menyajikan proses belajar yang nyata dan menjadikan peserta didik lebih aktif, serta membuat peserta didik dapat membangun atau membentuk pengetahuan baru berdasarkan pengalaman belajarnya. Pelaksanaan pembelajaran tematik terpadu dengan pendekatan kontruktivisme di Sekolah Dasar. Adapun tahapan pelaksanaan pembelajaran yang konstruktivis Widodo (Aini \& Relmasira, 2018) menyatakan bahwa pembelajaran yang konstruktivis terdiri dari 5 tahapan yang saling berurutan, yaitu: 1 . Pendahuluan: Tahap penyiapan pembelajar untuk mengikuti kegiatan pembelajaran. 2. Eksplorasi: Tahap pengidentifikasian dan pengaktifan pengetahuan awal pembelajar. 3 . Restrukturisasi: Tahap pengetahuan awal pembelajar agar terbentuk konsep yang diharapkan. 4. Aplikasi: Tahap penerapan konsep yang telah dibangun pada konteks yang berbeda ataupun dalam kehidupan sehari-hari. 5. Review dan Evaluasi: Tahap peninjauan kembali apa yang telah terjadi pada diri pembelajar yang berkaitan dengan suatu konsep yang sudah dipelajari.

Penerapan pendekatan kontruktivisme dalam pembelajaran tematik terpadu di kelas 4, Tema 5. Pahlawanku, Sub Tema 1 Perjuangan Para Pahlawan di SD negeri Sumogawe 01 Kab. Semarang melalui 3 tahapan proses pembelajaran:

\section{Persiapan Pembelajaran}

Membuat pemetaan kompetensi dasar, pengembangan jaringan tema,pengembangan silabus, dan penyusunan rencana pelaksanaan pembelajaran. Persiapan guru berupa penetapan jadwal yang disusun berdasarkan tema dan tidak lagi disusun berdasarkan mata pelajaran. Penyusunan jadwal mengikuti model jadwal pembelajaran tematik secara terintegrasi. Penyusunan Rencana Pelaksanaan Pembelajaran (RPP). RPP yang digunakan adalah RPP versi terbaru dengan 3 komponen yakni berisi tentang tujuan pembelajaran, langkah-langkah pembelajaran dan inti.

\section{Pelaksanaan Pembelajaran}

Deskripsi kegiatan pembelajaran 
Tematik Kelas 4, Tema.5, Sub Tema 1 sebagai berikut :

\section{(1) Kegiatan Awal;}

a. Kelas dimulai dengan dibuka dengan salam, menanyakan kabar dan mengecek kehadiran peserta didik

b. Kelas dilanjutkan dengan do'a dipimpin oleh salah seorang peserta didik. Peserta didik yang diminta membaca do'a adalah peserta didik peserta didik yang hari ini datang paling awal. (Menghargai kedisiplikan peserta didik/PPK).

c. Peserta didik diingatkan untuk selalu mengutamakan sikap disiplin setiap saat dan menfaatnya bagi tercapainya sita-cita.

d. Menyanyikan lagu Garuda Pancasila atau lagu nasional lainnya. Guru memberikan penguatan tentang pentingnya menanamkan semangat Nasionalisme.

e. kegiatan literasi; peserta diajak guru untuk mendiskusikan buka yang dibaca peserta didik sebelum pembelajaran dimulai dengan pertanyaan-pertanyaan berikut:

- Apa yang tergambar pada sampul buku.

- Apa judul buku

- Kira-kira ini menceritakan tentang apa

\section{(2) Kegiatan Inti;}

a. Sebelumnya guru menempelkan gambar seorang anak yang membantu kakek menyeberang jalan.

b. Guru meminta pendapat peserta didik tentang kejadian yang ada di dalam gambar. Guru membuat kesimpulan bahwa anak tersebut memiliki sikap kepahlawanan yaitu berkorban untuk membantu orang lain yang membutuhkan.

c. Guru menyampaikan informasi kepada peserta didik bahwa mereka akan banyak belajar tentang nilai-nilai kepahlawanan dari Raja-Raja di masa Hindu, Budha dan Islam.

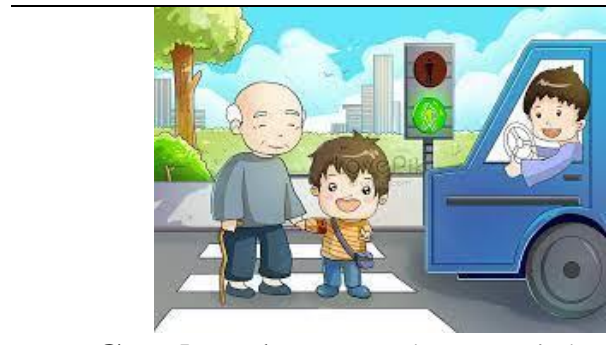

Gambar 1. Menyeberang jalan raya

d. Berdiskusi

- Peserta didik diminta untuk mengamati gambar yang ada pada buku siswa halaman 2. Guru memberi waktu sekitar 15 menit untuk berdiskusi.

- Setiap peserta didik kemudian menjawab pertanyaan yang ada dan mendiskusikan jawabannya di kelompok masing-masing.

- Guru membimbing diskusi, berjalan berkeliling dari kelompok satu ke kelompok lain untuk memastikan bahwa setiap anggota berpartisipasi aktif.

- Selama proses diskusi guru menggunakan penilaian rubrik.

- Guru mengajak satu atau dua peserta didik untuk menyampaikan hasil diskusinya, lalu memberi penguatan kepada seluruh peserta didik mengenai jawaban yang diharapkan. Guru dapat memberi kesempatan kepada seluruh peserta didik untuk memberikan komentar dari jawaban yang ada. Guru tidak menjawab langsung namun memberi kesempatan kepada peserta didik lain untuk mencoba menjawab pertanyaan yang diajukan oleh temannya. Guru dapat menguatkan jawaban-jawaban yang ada. (Critical Thinking and Problem Solving)
(3) Penutup;
a. Renungkan
b. Peserta didik melakukan refleksi dengan menjawab pertanyaan yang terdapat dalam buku peserta didik.
c. Belajar dirumah bersama Orangtua
d. Peserta didik diminta untuk mendiskusikan nilai-nilai 


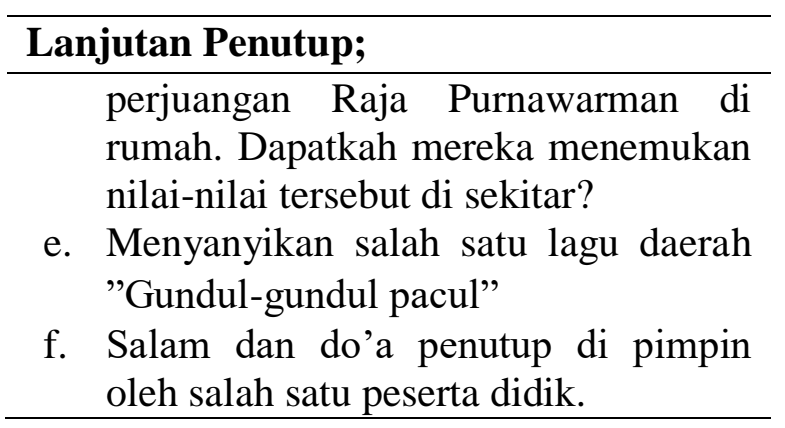

\section{Hasil Pelaksanaan Pembelajaran}

Dari kegiatan hasil pembelajaran menunjukan kegiatan peserta didik yang belajar secara langsung dari pengalamannya terlihat saat kegiatan pembelajaran yaitu: (1) kegiatan diskusi hasil membaca peserta didik sebelum pembelajaran dimulai. (2) Kegiatan guru menempel gambar dan peserta didik diminta menceritakan pengalamnnya yang pernah dialami seperti di gambar. (3) Ketika peserta diskusi berdiskusi untuk menyelesaikan soal pertanyaan. (4) Guru memberikan kesempatan peserta didik menjawab pertanyaan dari hasil belajarnya. Peserta didik hasil pembelajarn akan lebih bermakna, karena peserta diidk terlibat dan berperan langsung dalam pembelajaran melalui pemecahan masalah. Hal ini sesuai dengan pendekatan konstruktivistik yang berpandangan bahwa melalui pengalaman langsung peserta didik dapat mengkonstruksi pengetahuan yang diperolehnya, pembelajaran tematik juga menyajikan proses belajar yang nyata dengan kehidupan peserta didik. Pendekatan konstruktivistik dan pembelajaran tematik, keduanya menyajikan proses belajar yang nyata dan menjadikan peserta didik lebih aktif, serta membuat peserta didik dapat membangun atau membentuk pengetahuan baru berdasarkan pengalaman belajarnya.

Jadi pembelajaran konstruktivisme menurut Karli dan Margaretha, Poedjiadi, Trianto, (2002, 2005, 2009) adalah suatu pandangan yang mendasarkan bahwa perolehan pengetahuan atau konstruksi (bentukan) dari orang yang sedang belajar yang diawali dengan terjadinya konflik kognitif yang terjadi pada akhir proses belajar pengetahuan dan akan dibangun oleh melalui pengalamannya dari hasil interaksi dengan lingkungannya.

\section{UCAPAN TERIMA KASIH}

Terima kasih diberikan kepada dosen pembimbing mata kuliah Filsafat Pendidikan Universitas Muhammadiyah Surakarta. Selain itu terima kasih diberikan kepada kepala sekolah, guru dan peserta didik SD Negeri Sumogawe 01 Kab.Semarang atas Kerjasama dalam kegiatan observasi.

\section{KESIMPULAN}

Aliran konstruktivisme berpandangan bahwa belajar merupakan hasil konstruksi peserta didik terhadap pengalaman belajarnya. Begitu juga yang diharapkan oleh pembelajaran tematik yaitu, peserta didik dapat membangun pengetahuannya sendiri setelah terlibat langsung dan aktif dalam pembelajaran. Untuk itu pembelajaran tematik menyajikan kegiatan pembalajaran yang berpusat pada peserta didik dan menghadirkan kondisi nyata bagi peserta didik. Berdasarkan hasil pengakajian dan hasil penelitian terdahulu maka pembelajaran tematik merupakan model pembelajaran yang baik dan layak untuk digunakan dalam pembelajaran di kelas. Pembelajaran tematik apabila dilaksanakan sesuai dengan prinsip dan tujuan serta berpedoman pada landasannya maka pelaksanaan pembelajaran tematik akan sangat baik dan bermakna bagi peserta didik.

Pelaksanaan pembelajaran tematik yang berlandaskan pendekatan konstruktivistik diharapkan dapat menjadikan pembelajaran yang dapat membuat 
pesertadidik menjadi lebih aktif dan mampu membangun pengetahuan yang baru. Pelaksanaan pembelajaran ini juga membutuhkan partisipasi aktif dari guru karena guru merupakan pelaksana pembelajaran di kelas.

\section{DAFTAR RUJUKAN}

Aini, Q., \& Relmasira, S. C. (2018). Penerapan Pembelajaran Tematik Integratif Berbasis Kontekstual Meningkatkan Keaktifan dan Hasil Belajar Siswa Kelas 1 SD. Sekolah Dasar: Kajian Teori Dan Praktik Pendidikan, 8285(November), 124 132.

Anu Beatrix, Ruminitai, F. (2017). Pendekatan konstruktivistik dalam pelaksanaan pembelajaran tematik terpadu di sekolah dasar. Prosiding TEP \& PDs, Tema: 6 Nomor: 10 Bulan Mei Tahun 2017, 630-636.

Darmalaksana, W. (2020). Metode Penelitian Kualitatif Studi Pustaka dan Studi Lapangan. Pre-Print Digital Library UIN Sunan Gunung Djati Bandung, 16.http://digilib.uinsgd.ac.id/32855/1/M etode Penelitian Kualitatif.pdf

Fitriadi, M., \& Sabri, T. (2018). Pengaruh pendekatan konstruktivistik terhadap perolehan belajar tematik peserta didik kelas iv sekolah dasar. Jurnal Pendidikan Dan Pembelajaran Khatulistiwa, $\quad 7, \quad$ 1-8. https://jurnal.untan.ac.id/index.php/jpd pb/article/view/28841

Fitriadi, M., \& Sabri, T. (2019). Penggunaan Sumber Belajar dalam Pembelajaran Tematik di SD/MI. Jurnal El - Hamra, 4(2), 65-71. http://ejournal.elhamra.id/index.php/el/article/view/14

Liadi, H. F., Darim, H. A., \& Warjuningsing,
T. (2018). Penerapan pendekatan konstruktivisme sebagai upaya meningkatkan kemampuan membaca pemahaman interpretatif bagi siswa. Jurnal Transformatif, 2(1), 17-26. http://e-journal.iain palangkaraya.ac.id/index.php/TF\%0A Vol.

Muhsinin, U., Musyaddad, K., \& Azim, F. (2019). Keywords: Integrative thematic , character Kata Kunci : Tematik integratif , karakter PENDAHULUAN Pembelajaran merupakan sebuah kegiatan yang memiliki nilai edukatif ( Bahri , 2010 ). Pembelajaran bukan lagi usaha untuk menyampaikan pengetahuan tetapi ju. Al-Tadzkiyyah: Jurnal Pendidikan Islam, 10(I), 51-68. https://doi.org/https://doi.org/10.24042/ atjpi.v10i1.3626

Rahmawati, Chumdari, K. (2021). Analisis penggunaan media dalam pembelajaran tematik ditinjau dari teori belajar konstruktivisme di kelas $\mathrm{v}$ sekolah dasar. Didaktika Dwija Indria, 9(449). https://jurnal.uns.ac.id/JDDI/article/vie w/48975

Supardan, D. (2016). Teori dan Praktik Pendekatan Konstruktivisme dalam Pembelajaran. Edunomic, 4(1), 1-12. http://www.fkipunswagati.ac.id/ejournal/index.php/edu nomic/article/view/199

Utari, U., Degeng, I. N. S., \& Akbar, S. (2016). Pembelajaran Tematik Berbasis Kearifan Lokal Di Sekolah Dasar Dalam Menghadapi Masyarakat Ekonomi Asean (MEA). JTP2 IPS, 1(Vol 1, No.1; April 2016), 39-44. http://journal2.um.ac.id/index.php/jtppi ps/article/view/226 